\title{
THE USE OF NITROGEN ON HILL COUNTRY
}

\author{
R. R. SHERLOCK
}

\author{
Ministry of Agriculture und Fisheries, Roforua
}

\author{
M. B. O'CONNOR \\ Ruakura Agricultural Research Cenfre, Hamilton
}

\section{Abstract}

Results from trials at Te Kuiti in 1971 and 1972 substantiated for the better fertility Mairoa Ash soils the results obtained from nitrogen trials elsewhere in New Zealand. High responses (24 to $39 \mathrm{~kg} \mathrm{DM} / \mathrm{kg} \mathrm{N}$ for applications of $2.5 \mathrm{~kg} \mathrm{~N} / \mathrm{ha}$ ) were obtained from early spring applications.

Substantial carry-over responses (up to $65 \%$ of total response) were measured for applications made in the cold winter months of 1972. Evidence from overseas and New Zealand is reviewed which suggested higher residual responses to applied nitrogen in grazing trials than in mown plot trials.

An economic analysis based on the Te Kuiti trial results investigates the profitability of hay versus nitrogen, and optimum rates of nitrogen application for two cattle fattening policies. Some practical aspects of using nitrogen on King Country farms are considered.

\section{INTRODUCTION}

THE use of applied nitrogen has been increasing rapidly in the last 3 years. Most of the nitrogen used on pasture has been on dairy farms, However, there are some farmers in the King Country who have been using nitrogen successfully to provide out-of-season pasture for beef cattle for the last 4 years. An -economic analysis based on results from nitrogen trials at the Te Kuiti Field Research Area and relevant information from other current related trials endorses the lead given by these men and suggests a more widespread use of applied nitrogen by King Country farmers is warranted.

The Te Kuiti nitrogen trials conducted in 1971 and 1972 were an extension of a New Zealand-wide series reviewed by O'Connor and Gregg (1971) which demonstrated that, in most districts, profitable responses are likely from autumn and spring applications of nitrogen. In these series and in Ball's work (1970) responses were measured by a single harvest. The results suggest a marked seasonal response pattern to monthly nitrogen applica- 
tions 'between April and October with greatest responses in months where growing conditions were best and vice versa. Hall's results showed increasing yields as the spell before harvest increased up to 8 weeks.

A modification to the 1972 trials at the Te Kuiti Field Research Area demonstrated carry-over responses of up to $65 \%$ to two extra harvests. In fact, the results suggest the total response to a kilogram of nitrogen is likely to be similar regardless of when it is applied during he months April to September and that it is only the time it takes to obtain the responses that differs with the month of application. For farmers the implications are greater flexibility; first, in when nitrogen can be applied to achieve profitable responses and, secondly, in when grazing can occur after applications.

A further major gain for farmers is suggested by preliminary results from trials at present being conducted by $\mathrm{C}$. During (pers. comm.) and by P. R. Ball, J. Mauger and J. A. H. Inglis (pers. comm.). Results indicate greater responses to fertilizer nitrogen where areas are grazed by animals than when measured in plot trials with clippings removed, as they were in the previously mentioned trials. This agrees with overseas work (e.g., Brockman, 1969; Brockman et al., 197 1) which in addition suggests that the reason is the recycling of nitrogen by grazing animals as opposed to the total removal of nutrients in mowing trials.

In this paper the results of the 1971 and 1972 Te Kuiti Field Research Area nitrogen trials, whose object was to measure the ability of applied nitrogen to produce out-of-season pasture in the King Country, are presented together with preliminary results from C. During's nitrogen grazing trial. An economic assessment of these results has been made, along with suggestions for their application under King Country farming conditions.

\section{TRIAL DESIGN}

The Te Kuiti Field trials consisted of rates of $0,25,50$ and $100 \mathrm{~kg} \mathrm{~N} /$ ha replicated 6 (times and laid down at monthly intervals over the April to October period in 1971 and 1972 seasons, on a high-producing perennial ryegrass/white clover sward on Mairoa Ash.

Nitrogen was applied mid to late in the month and the pasture harvested approximately 4 weeks later. Thus April responses were from nitrogen applied on April 20 and \{harvested on May 20. In June and July periods, spelling times were lengthened to 
6 and 8 weeks. In August plots were spelled for 4 weeks again and this was reduced to 2 and 3 weeks, respectively, for September and Ootober 'applications.

The 1972 series were modified to measure carry-over nitrogen responses as well, by re-cutting trials a second and third 'time at intervals approximating normal grazing intervals for that time of the year.

\section{RESULTS AND DISCUSSION}

\section{Response Pattern to Nitrogen}

The pasture response pattern for the first cut, for $50 \mathrm{~kg} \mathrm{~N} / \mathrm{ha}$ compared with no nitrogen is shown in Fig. 1.

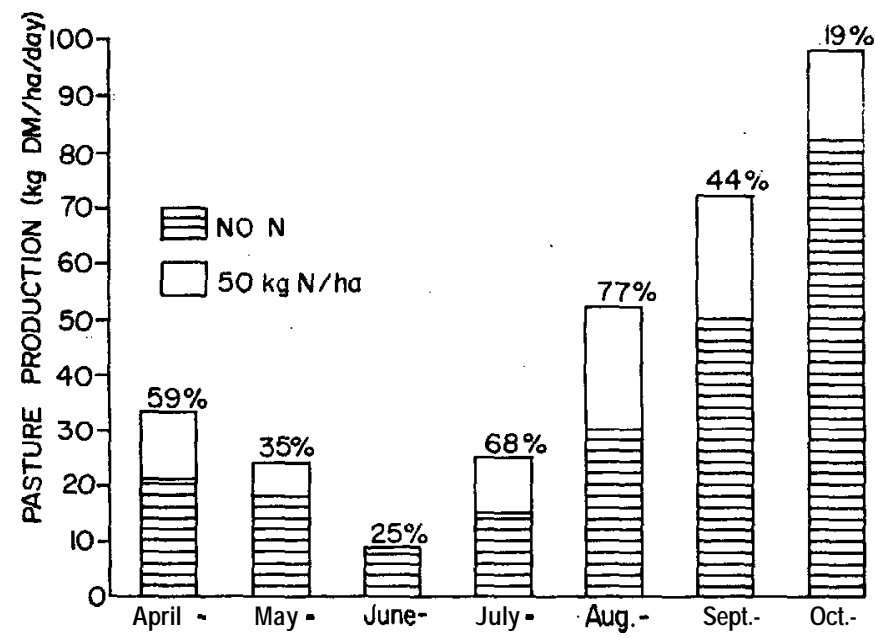

FIG. 1: Percentage response in pasture production fo applied nitrogen over the April- 0 ctober period.

These data confirm for the King Country what other work has shown elsewhere, that best percentage and total dry matter responses are obtained from early spring 'applications of nitrogen, in particular August applications.

\section{Residual Responses}

A definite pattern of carry-over responses was obtained for nitrogen applications where a second and third harvest was taken from plots, as illustrated, relative to total responses, in Fig. 2 for applications of $50 \mathrm{~kg} \mathrm{~N} / \mathrm{ha}$. The better the growth con- 


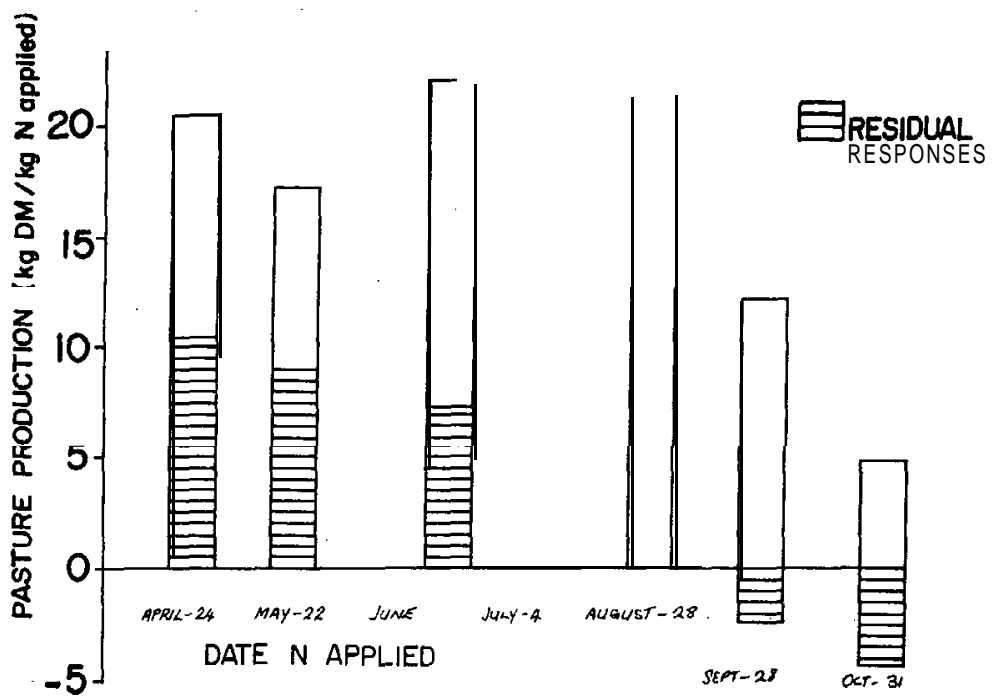

FIG. 2: Total pasture production showing residual responses for $\mathbf{N}$ applied at $50 \mathrm{~kg} / \mathrm{ha}$ over the A pril-0 ctober period 1972.

ditions immediately following the application, the smaller the residual effect.

A similar pattern was obtained for 25 and $100 \mathrm{~kg} / \mathrm{ha}$ rates, except that for the $100 \mathrm{~kg}$ applications the residuals made up a greater proportion of the total responses and the negative residual responses for September and October applications were less important.

\section{EFficiency OF Responses}

It can be seen from Fig. 2 that when residual responses are included there is little difference between total responses for nitrogen applications made between April and the beginning of September. This is in marked contrast to the situation illustrated in Fig. 1 where only initial responses are considered. The position is summarized in Table 1 using efficiency of nitrogen applications measured as $\mathrm{kg} \mathrm{DM}$ produced $/ \mathrm{kg} \mathrm{N}$ (applied. Lower responses to applied nitrogen can be expected after the spring flush begins, at the end of September in this trial.

\section{ThE EFFECT OF GRAZING}

In a trial where nitrogen was 'applied at the end of July to pastures on a Waiotu soil in North Auckland, C. During (pers. 
TABLE 1: EFFICIENCY OF NITROGEN RESPONSES AT TE KUITI (kg DM/kg N applied)

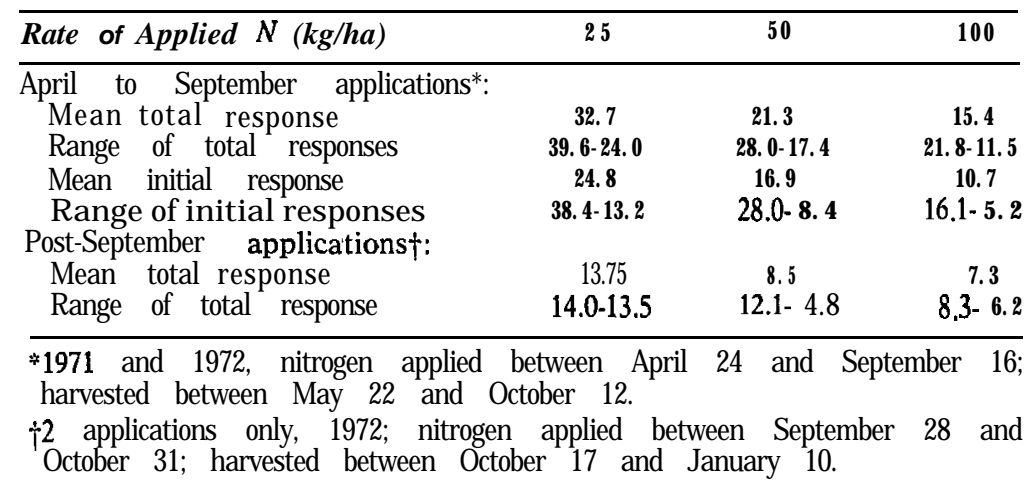

TABLE 2: NITROGEN RESIDUAL RESPONSES MEASURED FOR UNGRAZED AND GRAZED AREAS (56 kg/ha applied $\mathrm{N}-$ yield increases in $\mathrm{kg} \mathrm{DM} / \mathrm{ha}$ )

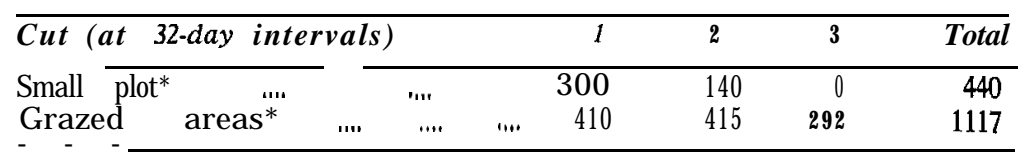

*64 pairs of ungrazed small plots located in the 0.6 ha grazed areas (16 replicates) stocked with rising l-year steers tit 5.25 and 5.86/ha. Grazed area responses measured by the frame technique.

comm.) compared dry matter production from ungrazed plots and plots grazed by weaner cattle, and showed a $154 \%$ increase in dry matter response from the grazed over the non-grazed area. Indications are that similar results might be expeoted under set-stocking with sheep where pastures are first spelled for 2 weeks after the application of nitrogen (P. R. Ball et ccl., pers. comm.).

\section{IMPLICATIONS FOR FARMERS}

Work at the Te Kuiti Research Area indicates:

(I) Large DM responses to nitrogen applied between April and October on the higher fertility areas of Mairoa Ash with between 40 and $50 \%$ ryegrass in the sward.

(2) Greater responses measured in $\mathrm{kg} \mathrm{DM} / \mathrm{kg} \mathrm{N}$ applied are obtained at lighter application rates. 


\section{USE OF NITROGEN}

(3) Except possibly in wet, cold winters, the total response/ $\mathrm{kg} \mathrm{N}$ applied is approximately the same, regardless of when nitrogen is applied from April to before the onset of the spring flush.

(4) Responses to applications after the onset of the spring flush, about the end of September, will be smaller per kilogram nitrogen applied and there may be some slumping, especially when bay is cut.

(5) Best initial responses will be obtained when climate and soil conditions favour growth - i.e., August and September in spring, and April in autumn.

Other research work and experience suggest:

( 1) A smaller DM response would be expected under poorer fertility conditions where there was less ryegrass in a pasture.

(2) Where responses to applied nitrogen are harvested by grazing animals, the recycling of nitrogen is likely to give even greater responses than would be indicated under similar conditions by mowing trials. The effect is likely to be greatest under sheep, less under beef cattle, and least under milking dairy cows.

\section{PROFITABILITY OF NITROGEN}

\section{NITROGEN VERSUS HAY}

Where cattle are being maintained or grown slowly, hay, within limits, is a substitute for applied nitrogen provided nitrogen application's are planned ahead.

Within these constraints, it can be seen from Table 3 that it could be 3 to 7 times more profitable to use nitrogen in place of hay in the King Country.

\section{RATE OF NITROGEN}

A look at the marginal increases of DM obtained from each additional 25 units of nitrogen 'applied helps determine the most economical rate to use. These values for the Te Kuiti trials are given on the nitrogen response curves in Fig. 3. They indicate that where, on a given farm, there is no shortage of suitable ryegrass pasture on which to apply nitrogen, other things being equal, the most economical rate to use whether total, initial, or post-September responses are considered, is 25 units. This is be- 
TABLE 3: COST OF HAY VERSUS NITROGEN PASTURE (160 bales/ ha medium quality hay at $22 \mathrm{~kg} \mathrm{DM} /$ bale)

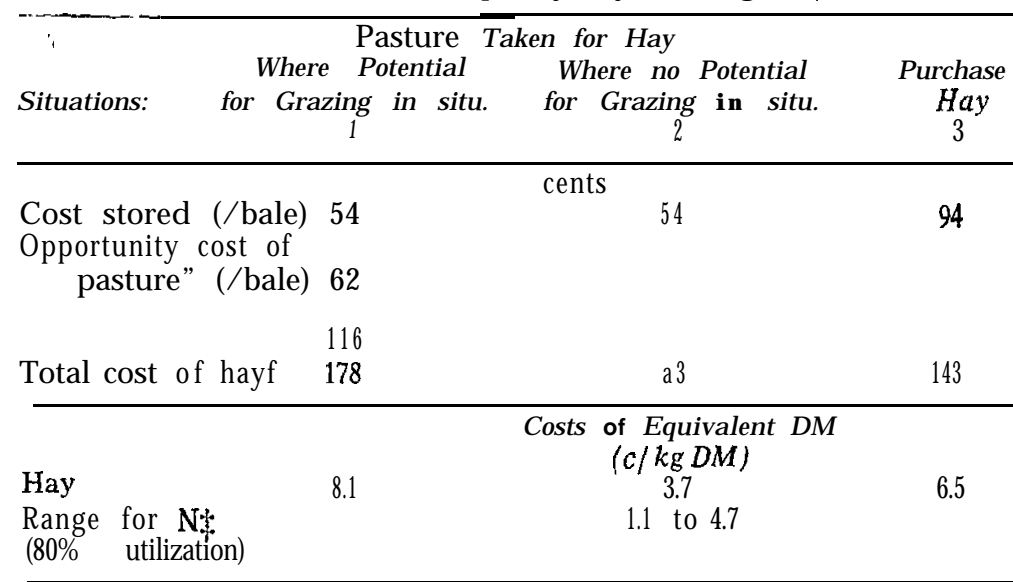

*22 kg DM hay stored = $31 \mathrm{~kg}$ DM pasture at 2c/kg (cf. pasture values Fig. 3).

+ Equivalent to $22 \mathrm{~kg}$ DM N pasture after $35 \%$ allowance for wastage and quality adjustments.

+From Table 1, mean total $\mathrm{N}$ responses, $\mathrm{N}$ at 28 cents/ kg applied.

cause the first 25 units of nitrogen gives a much greater increase than any of the successive 25 units.

Where more feed is required than can be grown on the ryegrass pastures available with 25 units of $\mathrm{N} / \mathrm{ha}$ a decision cannot be made based on information from the present trials, on whether it is more economical to apply extra nitrogen as a second 25 units to the ryegrass areas or whether it should be applied as 25 units/ha on areas of less responsive pastures.

\section{Determination of Optimum Rates}

When the area of ryegrass pasture on a farm to which nitrogen can be applied is limited, and assuming other pasture areas available produce less at all relevant rates of nitrogen than the ryegrass 'areas, then the most profitable rate of nitrogen to use would depend on the cost of nitrogen and the, value of extra pasture produced and utilized.

For pasture valued under two systems of cattle fattening under the conditions set out for Fig. 3, the optimum rate of nitrogen to apply could be demonstrated as that which gives the greatest distance between the expense line and the nitrogen response curve being considered. 


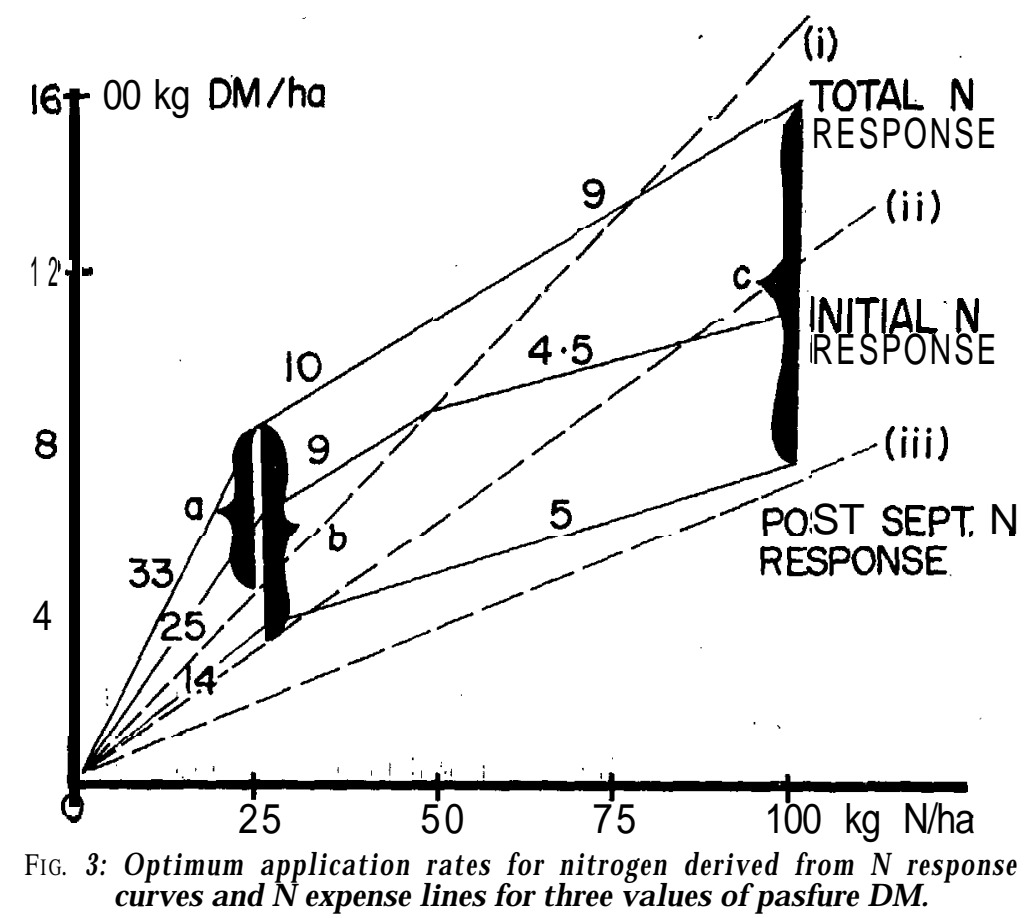

The three $\mathrm{N}$ response curves are derived from Table 1 . Values set out on the curves are the marginal responses $\mathrm{kg} \mathrm{DM} / \mathrm{kg} \mathrm{N}$ applied/ha. Lines (i), (ii), (iii) are the total cost lines, $C_{\mathrm{i}}$ for $\mathrm{N}$ where $C_{\mathrm{i}}=Y_{\mathrm{o}}+c / P_{\mathrm{j}} . X$ and where $i=(\mathbf{i})$, (ii), and (iii) for $P_{1}, P_{2}$, and $P_{3}$, respectively.

$Y_{0}=$ Pasture yield when no $\mathrm{N}$ is applied.

$\mathrm{X}=$ Amount of $\mathrm{N}$ applied in $\mathrm{kg} / \mathrm{ha}$.

$\mathrm{c}=28$ cents, the cost of a $\mathrm{kg}$ of $\mathrm{N}$ applied.

$P_{i}=$ Value of a $\mathrm{kg}$ of pasture DM.

$P_{1}=1.65 \mathrm{c}$ for pasture used by slow growth rate cattle with $66 \%$ utilization.

$P_{2}=2.33$ c for pasture used by fast growth rate cattle at $80 \%$ utilization.

$p_{3}=4.0 \mathrm{c}$ for pasture provided in winter-early spring which enables fast growth rates to be achieved instead of slow growth rates, at $80 \%$ utilization.

Pasture values are based on a slow and fast rate of fattening cattle each considered at two utilization rates, $80 \%$ and $66 \%$. Weaners are purchased in December at $\$ 65(55 \mathrm{c} / \mathrm{kg}$ liveweight) and sold at $181 \mathrm{~kg}$ carcass weight in either (a) December or (b) March. A schedule of $\$ 90 / 100 \mathrm{~kg}$ carcass weight is used or $50 \mathrm{c} / \mathrm{kg}$ net of variable costs.

(a) Pasture values for fast growth rate cattle are:

$80 \%$ utilization, $2.33 \mathrm{c} / \mathrm{kg} \mathrm{DM} ; 66 \%$ utilization $1.91 \mathrm{c}$.

(b) Similar pasture values for slow growth rate cattle are:

$2.00 \mathrm{c}$ and $1.65 \mathrm{c}$. 
Some useful guidelines can be deduced.

If total response is considered to be utilized by extra, slowgrowth cattle achieving $66 \%$ utilization (line (i), Fig. 3), which is typical of much King Country cattle fattening, the optimum rate of nitrogen is $25 \mathrm{~kg} / \mathrm{ha}$ and it will give a net profit ((a), Fig. 3) of $\$ 6.50$. Post-September applications are not profitable. Under the same assumptions, but achieving fast growth rates and $80 \%$ utilization (line (ii) ), the optimum rate of nitrogen is still $25 \mathrm{~kg} / \mathrm{ha}$, but net profit, (b), has increased to $\$ 12.10$. Post-September applications of $25 \mathrm{~kg} / \mathrm{ha}$ are just profitable.

If the use of nitrogen achieves a change from slow growth rates at $80 \%$ utilization to fast growth rates - i.e., from finishing beasts in March to finishing them in December (line (iii)), and the total response curve is relevant, then the optimum rate of nitrogen is $100 \mathrm{~kg} / \mathrm{ha}$. This would give a net profit (c) of $\$ 33.60$. The cost of the nitrogen would be $\$ 28$ applied.

The examples given show that the use of nitrogen in the early spring and autumn can be very profitable with high prices being received for beef. Applications after the onset of the spring flush in many cases may not be profitable. However, this analysis does not set out to be exhaustive. Circumstances can readily be visualized when the return from applied nitrogen could be much greater than considered here.

\section{Fattening Cattie}

To date most of the nitrogen used in the King Country has been for providing extra feed for dry cattle. The discus\&on of Fig. 3 demonstrates. its profitability. Most applications have been in April and May with little going on in the early spring months. With the carry-over of responses info the spring suggested by the Te Kuiti trials, this practice fits in well with the farmers' lower seasonal work load in late autumn.

However, for the following reasons greater use of July and August applications is warranted. In a wet winter there could be greater reductions of total responses to autumn applications than the information presented here would suggest. Secondly, animals tend to grow better over the spring months on, any given diet than at other times of the year, so that sufficient feed should be made available in spring to make full use of this potential.

As already demonstrated (Fig. 3), beef is produced more economically at fast growth rates. This can be achieved by more efficient utilization of existing feed especially in the winter-early 
spring period as well as with extra feed produced by nitrogen. An intensive unit located on the easier areas of Mairoa Ash country which are present on most farms Seems an excellent system for achieving this.

\section{Wintering Cows}

More and more farmers are discovering the advantages of wintering the breeding cows on areas separate from sheep. There is also an increase in farmers rationing this 'feed off with an electric fence. They are finding 'they can achieve higher stocking rates with this more efficient utilization of existing feed. Advantages have been better grown weaners, better conception rates in the cows, less grass-staggers and fewer cow mortalides. The use of applied nitrogen is a natural adjunct to this system.

The main feed deficit will be in June, July and August on the area where cows are wintered. This indicates April and July applications of nitrogen which, if used to substitute for half of the annual *hay requirements of 1200 bales for a typical farm with 120 cows, would require $330 \mathrm{~kg} \mathrm{~N}$ to be applied at $25 \mathrm{~kg} /$ ha on 13.2 ha. The savings in costs from hay alone (from Table 3) amount to $\$ 600$ or $\$ 228$ net, depending on whether situations 1 or 2 , respectively, apply, after allowing $\$ 92$ for nitrogen.

However, if extra spring feed can be created on the cattle unit by later applications for the August/September period, it would be possible to tighten the cows and allow some extra area for the ewes which have a peak feed requirement at this time.

\section{SHEEP}

The use of nitrogen for grazing by sheep is still a matter of hypothesis. The essential factor for its successful use is once again going to be the ability to ration the extra feed produced. With the suggested importance of recycling of nitrogen obtained through the grazing animal, in particular sheep, it would appear that worthwhile responses could he obtained even under setstocking, Nitrogen would be applied in late July to some of the sheep paddocks at the end of the winter rotation before 'spreading out the ewes for lambing. This area would be spelled for 2 or 3 weeks before stocking it with the earlier lambers.

The idea would be to apply a light rate, $25 \mathrm{~kg} / \mathrm{ha}$, over as large an area as possible. One method would be to "strip" the nitrogen over the area to avoid too great an accumulation of feed in one place. 


\section{ACKNOWLEDGEMENTS}

The authors wish to acknowledge the assistance of the Technicians of the Te Kuiti Field Research Area, the Farm Advisory Officers of the Ministry of Agriculture and Fisheries at Te Kuiti and Taumarunui, and C. During.

\section{REFERENCES}

Ball, P. R., 1970: Massey Sheepfmg A., 33: 11-9.

Brockman, J. S., 1969: J. Ir. Grassld Anim. Prod. Ass., 4: 13-9.

Brockman, J. S.; Rope, C. M.; Stevens, M. T., 1971: J. Br. Grassld Soc., 26: 209-12.

O’Connor, M. B.; Gregg, P. E. H., 1971: Proc. N.Z. Grassld Ass., 33: 26-34. 